\title{
Physico-Chemical Analysis of Different Soil Samples of Thiruvarur District, During the Rabi Cropping Season
}

\author{
H.Rasith Ali and P. Sudha \\ PG and Research Department of Chemistry, Thiru.Vi.Ka.Government Arts College, \\ Thiruvarur District, TamilNadu, India. \\ Affiliated to Bharathidasan University, Thiruchirappalli, Tamilnadu, India
}

\begin{abstract}
For studies of different parameters, such as total organic carbon (OC), nitrogen ( N), phosphorus ( P) potassium ( K), zinc ( Zn), iron (Fe), boron ( B), pH and electrical conductivity, soil analysis was carried out in the current research. This research leads us to believe that the quantity of soil nutrients in the district of Thiruvarur-Tamilnadu. The results indicate that all Thiruvarur villages have a medium or high mineral content on average. This knowledge would help farmers solve problems related to soil nutrients and determine the amount of fertiliser to be applied to the soil to improve crop yields.
\end{abstract}

\section{KEY WORDS: PHYSICOCHEMICAL, SOIL, CONDUCTIVITY, ORGANIC CARBON}

\section{INTRODUCTION}

A series of 15 samples of soil from the villages of the District of Thiruvarur, representing the soil of that village. The soil samples were obtained and gathered in polythene bags by normal procedure. In the summer season, all the samples were collected. These samples were analysed in the laboratory to quantify different chemical parameters using standard methods. (A K Gupta et. al. (1994)) Soil analysis is conducted for studies of different parameters such as total organic carbon, nitrogen $(\mathrm{N})$, phosphorus $(\mathrm{P})$ and potassium (K) $\mathrm{pH}, \mathrm{pH}$ calculation and estimates of, $\mathrm{K}+, \mathrm{PO} 4, \mathrm{NO}_{3}$. The soil percentage has been examined. Soil fertility depends on the concentration of $\mathrm{N}, \mathrm{P}, \mathrm{K}$, organic and inorganic materials, the conductivity of the water and the physicochemical properties needed for the growth of the plant, such as the moisture content, nitrogen as fertiliser. Potassium is used for the purpose of flowering, and phosphate is used for the growth of plant roots (K. Kanimozhi (2011), N.S Sonawane (2013), N N Garba (2013), K.P. Kordlaghari (2013).

Biosc Biotech Res Comm P-ISSN: 0974-6455 E-ISSN: 2321-4007
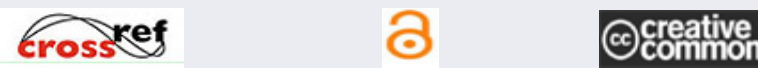

Identifiers and Pagination

Article Information

Year: 2021 Vol: 14 No (7) Special Issue

Received: $10^{\text {th }}$ May 2021

Pages: 263-267

Accepted after revision: $14^{\text {th }}$ July 2021

This is an open access article under Creative

Commons License Attribn 4.0 Intl (CC-BY).

DOI: $h t t p: / / d x . d o i . o r g / 10.21786 / b b r c / 14.7 .58$

\section{MATERIAL AND METHODS}

Study area: The district of Thiruvarur was carved out as a separate district by detaching Valangaiman Taluk from Thanjavur District and Thiruvarur, Nannilam, Kudavasal, Needamangalam, Mannargudi, Thirutturaippoondi Taluks from Nagappatinam District on 01.01.1997. It lies between 10o 20' and 11o 07' North latitude and 79o 15' and 79o $45^{\prime}$ 'East longitude. The total area of the district is 2,377 sq.km.

All the AR grade chemicals and reagents were used. The physicochemical parameter analysis of the soil samples was suspended in distilled water and the particles were allowed to settle down. Using a $\mathrm{pH}$ metre (Duralab, India), the suspension $\mathrm{pH}$ was determined. The electrical conductivity of the soil was measured using a conductivity metre in the water extract filtrate. By following chromic acid wet digestion method as a standard technique of the Walkley and Black method, the percent organic carbon (OC) content was calculated, available nitrogen was estimated by alkaline permanganate method (K K Borah (2009), I.Ifenna (2013), A F Aiyesanmi (2012)), available phosphorus calculated by volumetric method. Using turbidimetric methods, the available potassium content in the soil was determined (M C Onojake (2012), C C Trasar (2008), K Rajendren (2001), M M Lakdawala (2013). 


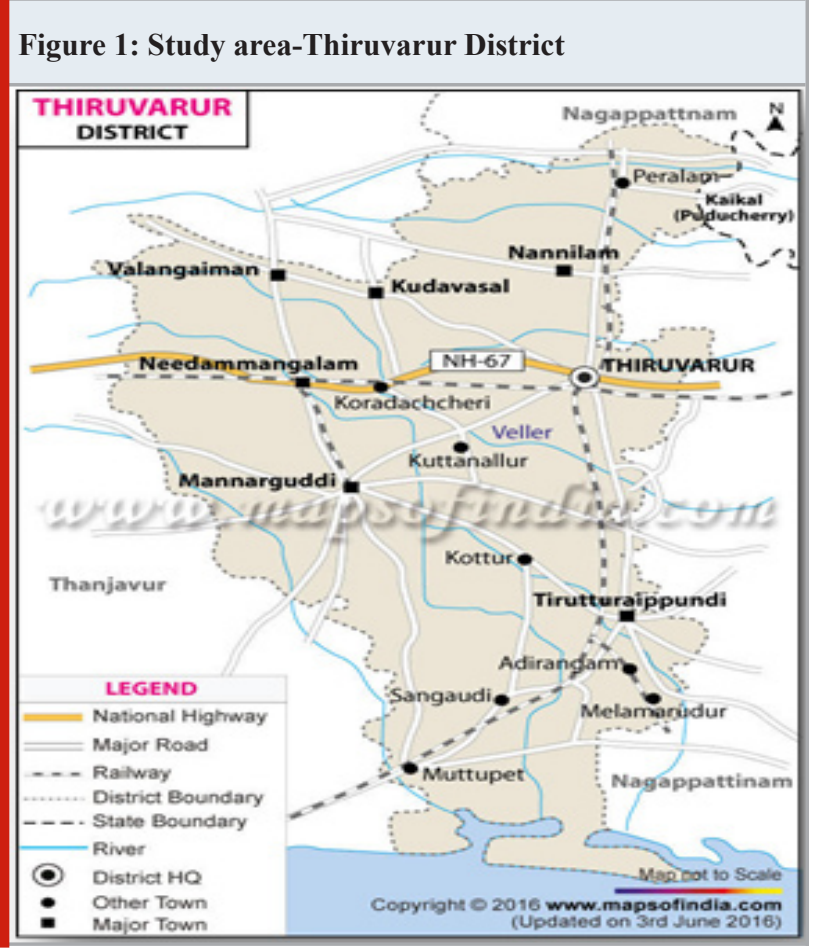

pH: A soil $\mathrm{pH}$ analysis of the Thiruvarur district samples was calculated for $\mathrm{pH}$ and observed within the range (6.607.90) of Table.1. Soil sample $\mathrm{pH}$ estimate was observed and resulted in a mildly acidic to moderately alkaline reaction (Table.2).

$\mathbf{E C}\left(\mathbf{d S m}^{-1}\right)$ : A research was performed for EC on electrical conductivity (EC) soil samples and observed in the range of $(0.25-0.80 \mathrm{dSm}-1)$ at $250 \mathrm{C}$ (Table.1) in the district of Thiruvarur. EC estimation of soil samples was observed and resulted in the salt-free nature of soil samples (Table.2).

Organic Carbon (OC\%) : Data provided in Table.1 analysed for organic carbon from the soil sample observed in the thiruvarur district range of $(0.19-0.50)$ percent (Table.1). The outcome indicates that the soil samples' organic carbon is within the low range (Table.2). High temperatures and good soil aeration have improved the rate of organic matter oxidation by reducing the organic carbon content. The prevailing high temperatures in the region are responsible for the rapid combustion of organic matter, resulting in the low organic carbon content of these soils. Sharma et.al (2008) also noted similar findings.

Table 1. Shows Physicochemical properties of soil samples from villages of Thiruvrur District

\begin{tabular}{|c|c|c|c|c|c|c|c|c|c|c|c|}
\hline $\begin{array}{l}\text { S. } \\
\text { NO }\end{array}$ & $\begin{array}{c}\text { Samples } \\
\text { No }\end{array}$ & $\begin{array}{l}\text { Soil } \\
\text { Type }\end{array}$ & pH & $\begin{array}{c}E C \\
\left(\mathrm{dS} \mathbf{~ m}^{-1}\right)\end{array}$ & $\begin{array}{l}\text { OC } \\
(\%)\end{array}$ & $\begin{array}{c}\mathrm{N} \\
\left(\mathrm{Kg} \mathrm{ha}^{-1}\right)\end{array}$ & $\begin{array}{c}\mathbf{P} \\
\left(\mathrm{Kg} \mathrm{ha}^{-1}\right)\end{array}$ & $\begin{array}{c}\mathrm{K} \\
\left(\mathrm{Kg} \mathrm{ha}^{-1}\right)\end{array}$ & $\begin{array}{c}\mathrm{Zn} \\
(\mathbf{p p m})\end{array}$ & $\begin{array}{c}\mathrm{Fe} \\
(\mathrm{ppm})\end{array}$ & $\begin{array}{c}\text { B } \\
(\mathrm{ppm})\end{array}$ \\
\hline 1 & SS1 & Riverbed Soil & 7.41 & 0.31 & 0.25 & 278 & 17.6 & 287 & 0.68 & 31.00 & 41.00 \\
\hline 2 & $\mathrm{SS} 2$ & Riverbed Soil & 7.20 & 0.30 & 0.24 & 273 & 19.2 & 285 & 0.84 & 33.50 & 46.20 \\
\hline 3 & SS3 & Riverbed Soil & 7.10 & 0.33 & 0.45 & 275 & 17.4 & 288 & 0.62 & 30.10 & 43.40 \\
\hline 4 & SS4 & Riverbed Soil & 6.95 & 0.62 & 0.50 & 260 & 17.6 & 298 & 0.40 & 30.50 & 50.30 \\
\hline 5 & SS5 & Riverbed Soil & 7.11 & 0.35 & 0.40 & 265 & 16.8 & 290 & 0.55 & 28.50 & 39.50 \\
\hline 6 & SS6 & Riverbed Soil & 7.23 & 0.60 & 0.20 & 278 & 18.5 & 272 & 0.60 & 33.0 & 45.30 \\
\hline 7 & SS7 & Paddy field soil & 7.35 & 0.25 & 0.35 & 278 & 18.3 & 286 & 0.80 & 35.00 & 45.00 \\
\hline 8 & SS8 & Paddy field soil & 7.80 & 0.40 & 0.28 & 285 & 19.0 & 287 & 0.75 & 38.00 & 38.50 \\
\hline 9 & SS9 & Pond soil & 7.90 & 0.80 & 0.28 & 287 & 20.4 & 292 & 0.60 & 36.50 & 40.00 \\
\hline 10 & SS10 & Garden soil & 7.52 & 0.25 & 0.19 & 280 & 16.7 & 282 & 0.70 & 36.50 & 45.40 \\
\hline 11 & SS11 & Barren land soil & 7.65 & 0.43 & 0.40 & 280 & 19.3 & 290 & 0.55 & 30.10 & 40.20 \\
\hline 12 & SS12 & Garden soil & 6.60 & 0.42 & 0.40 & 262 & 17.6 & 282 & 0.68 & 36.50 & 44.20 \\
\hline 13 & $\mathrm{SS} 13$ & Paddy field soil & 6.95 & 0.55 & 0.48 & 271 & 16.8 & 259 & 0.73 & 37.00 & 39.00 \\
\hline 14 & SS14 & Cotton field soil & 6.95 & 0.42 & 0.30 & 260 & 19.0 & 272 & 0.65 & 34.20 & 42.30 \\
\hline 15 & SS15 & Paddy field soil & 7.30 & 0.63 & 0.40 & 266 & 16.6 & 274 & 0.75 & 38.00 & 37.50 \\
\hline
\end{tabular}

Available macronutrients status of soils:

Available N: The N material available (Table.1) varies between $260-287 \mathrm{Kg}$ ha-1. Taking Table.3 into account the soil test rating for available $\mathrm{N}(<250$ as low, 250-500 as medium and $>500$ as high as $\mathrm{N}$ ), the soil sample was found to have a medium $\mathrm{N}$ content available. By the way, it was found that nearly all soil samples tested for usable $\mathrm{N}$ were deficient in N. Although, as suggested by Subbiah and Asija (1956), the available $\mathrm{N}$ analysed by the alkaline
$\mathrm{KMnO}_{4}$ method is valid.

Available P: In the study area, the available P content in different soils was in the range of (16.6-20.4) Kg ha-1 (Table.1). Table 3 displays the soil test ranking of the majority of soils for usable phosphorus $\left(0.10 \mathrm{Kg} \mathrm{ha}^{-1}\right.$ as very low, 11-20 $\mathrm{kg} \mathrm{ha}^{-1}$ as low, 21-40 $\mathrm{kg} \mathrm{ha}^{-1}$ as medium and $>40$ $\mathrm{kg} \mathrm{ha}^{-1}$ as high). In the available phosphorus, soil samples were observed under low to medium status. 
Available K: The results showed that the potassium content available ranged from (259-298) $\mathrm{kg} \mathrm{ha}^{-1}$ (Table.1). The soils with $0-50 \mathrm{~kg} \mathrm{ha}^{-1}$ as very low, 51-100 $\mathrm{kg} \mathrm{ha}^{-1}$ as low, 101-250 kg ha-1 as medium and $>250 \mathrm{~kg} \mathrm{ha}^{-1}$ as high in the potassium content available, are considered in Table.3. Both soil samples were found to be high in usable

Table 2. Interpretation of soil properties (Reference :MMSOIL-Gov.of India-2011(Methods Mannual et. al. (2011).

\begin{tabular}{|l|c|c|}
\hline \multirow{2}{*}{ Parameters } & & Interpretation \\
\hline \multirow{2}{*}{$\mathrm{pH}$} & $<4.6$ & Extremely acidic \\
& $4.6-5.5$ & Strongly acidic \\
& $5.6-6.5$ & Moderately acidic \\
& $6.6-6.9$ & Slightly acidic \\
& 7 & Neutral \\
& $7.1-8.5$ & Moderately alkaline \\
& $>8.5$ & Strongly alkaline \\
\hline EC dSm-1 & $0-2$ & Salt free \\
& $4-8$ & Slightly saline \\
& $8-15$ & Moderately saline \\
& $>15$ & Highly saline \\
\hline OC \% & $<0.5$ & Low \\
& $0.5-0.75$ & Medium \\
& $>0.75$ & High \\
\hline
\end{tabular}

potassium status.

Available Zn: The Zinc concentration range from $0.40 \mathrm{ppm}$ to $0.80 \mathrm{ppm}$ on all soil samples. The highest $\mathrm{Zn}$ content in soil was found in sample SS7. Zinc concentration was found to be below the range of deficiencies in all orchards. The key reasons for zinc deficiencies can be due to the existence of the parent material, the texture of the coarse soil, the low use of organic matter and soil micronutrient fertilizers. Zinc concentration in all areas was found to under deficiencies range. The main reasons for the deficiencies of zinc may be attributed to nature of parent material, coarse soil texture, low use of organic matter and micronutrient fertilizers of our soils.

Available Fe: The average iron in soil was $33.0 \mathrm{ppm}$. The iron content was significantly higher in SS8 with compare to other samples; it may be due to presence organic matter in soil. Generally, found that the availability of iron increased significantly with increase in organic carbon. The iron content in all the soil samples collected from district of Thiruvarur under high range. This might be due to presence of iron oxide in red soil of the region.

Availability B: Boron content was in the highest range in all regions, showing almost $38-50 \mathrm{pmm}$, from the results of soil analysis. It clearly demonstrates that the content of boron has exceeded the allowable limits. Usable boron demonstrated a positive and significant correlation The $\mathrm{pH}$, organic carbon and the soil's clay material.

Table 3. Permissible limit of the chemical properties.

\begin{tabular}{|l|c|c|c|c|}
\hline Properties & Very low & Low & Medium & High \\
\hline $\begin{array}{l}\text { Available Nitrogen in soil } \\
\left(\mathrm{kg} \mathrm{ha}^{-1}\right)\end{array}$ & - & $<250$ & $250-500$ & $>500$ \\
\hline $\begin{array}{l}\text { Available Phasphorus in soil } \\
\left(\mathrm{kg} \mathrm{ha}^{-1}\right)\end{array}$ & $0-10$ & $11-20$ & $21-40$ & $>40$ \\
\hline $\begin{array}{l}\text { Available Potassium in soil } \\
\left(\mathrm{kg} \mathrm{ha}^{-1}\right)\end{array}$ & $0-50$ & $51-100$ & $101-250$ & $>250$ \\
\hline
\end{tabular}

Source : Soil Plant and Water Analysis [14]

Table 4. Permissible limit of the chemical properties.

\begin{tabular}{|l|c|c|c|c|}
\hline Properties & Very low & Low & Medium & High \\
\hline $\begin{array}{l}\text { Available Zinc in soil } \\
(\mathrm{ppm})\end{array}$ & $0-0.5$ & $0.5-1.0$ & $1.0-3.0$ & $3.0-5.0$ \\
\hline $\begin{array}{l}\text { Available Iron in soil } \\
\text { (ppm) }\end{array}$ & $0-2.0$ & $2.0-4.0$ & $4.0-6.0$ & $6.0-10.0$ \\
\hline $\begin{array}{l}\text { Available Boron in soil } \\
(\mathrm{ppm})\end{array}$ & $0-0.2$ & $0.21-0.6$ & $0.61-1.11$ & $1.2-3$. \\
\hline
\end{tabular}

Source : Soil Plant and Water Analysis [14, 15]. 
Figuer 2: pH values of all soil samples

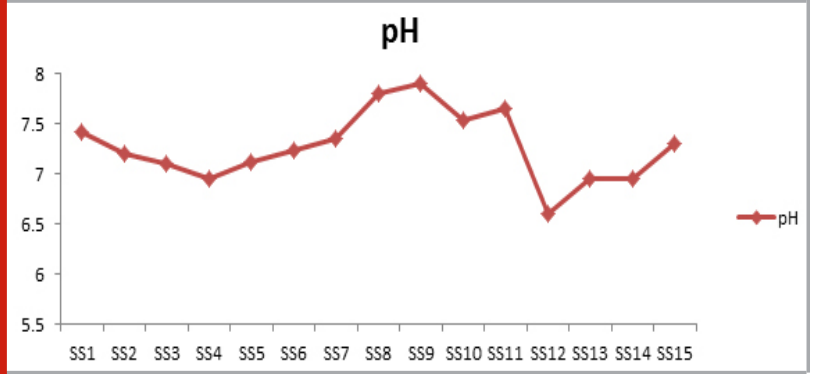

Figure 3. Electrical conductivity values of all soil samples

\section{$\mathrm{EC}(\mathrm{dS} \mathrm{m}-1)$}

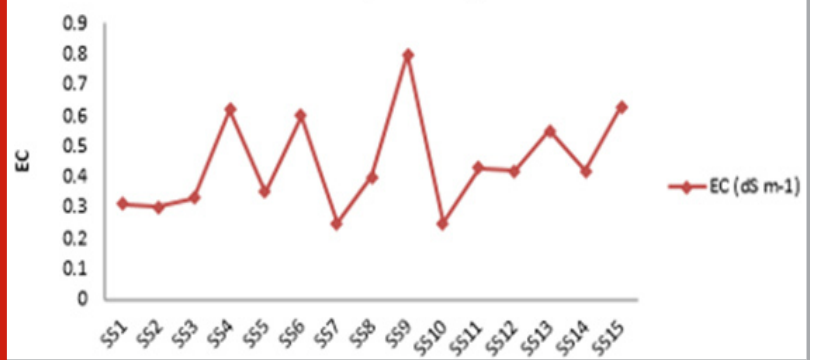

Figure 4: Organic carbon values of all soil samples

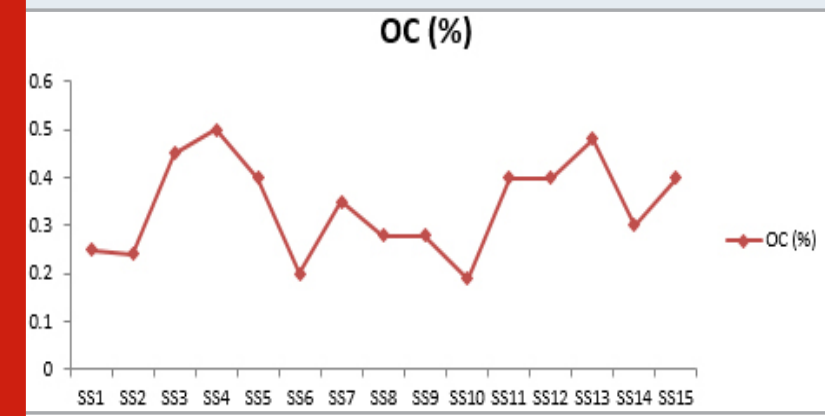

Figure 5: Nitrogen values of all soli samples

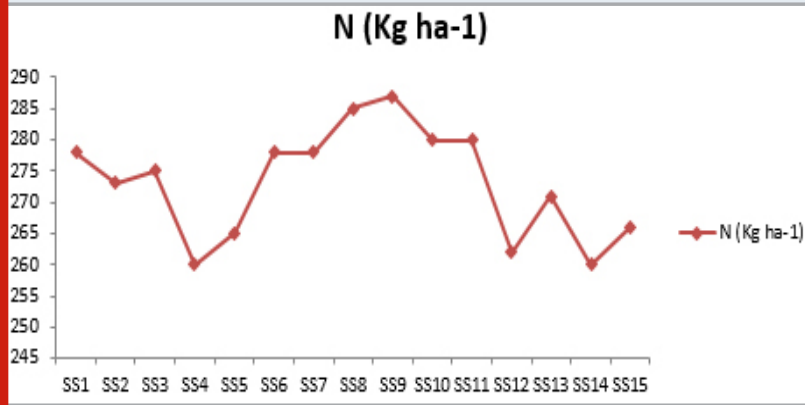

\section{CONCLUSION}

A physico-chemical analysis of soil samples from 15 villages in the district of Thiruvarur. These studies provide knowledge on the nature of soil nutrients present in the soil. It can be inferred from this analysis that a rich fertiliser is recommended for the available $\mathrm{EC}, \mathrm{PH}, \mathrm{OC}, \mathrm{N}, \mathrm{P}, \mathrm{K}, \mathrm{Zn}$, $\mathrm{Fe}, \mathrm{B}$ deficient soil. In different regions, the nutrient status
Figure 6: Phosphorus values of all soil samples

P (Kg ha-1)

SS1 SS2 SS3 SS4 SS5 SS6 SS7 SS8 SS9 SS10 SS11 SS12 SS13 SS14 SS15

Figure 7: Potassium values of all soil samples

\section{K (Kg ha-1)}

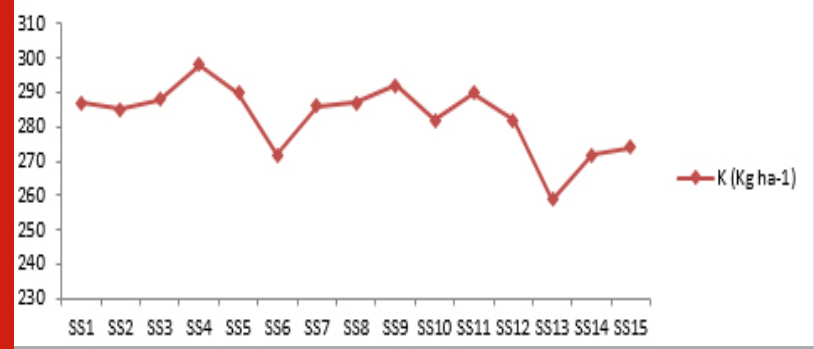

Figure 8: Zinc values of all soil samples

$$
\mathrm{Zn} \text { (ppm) }
$$

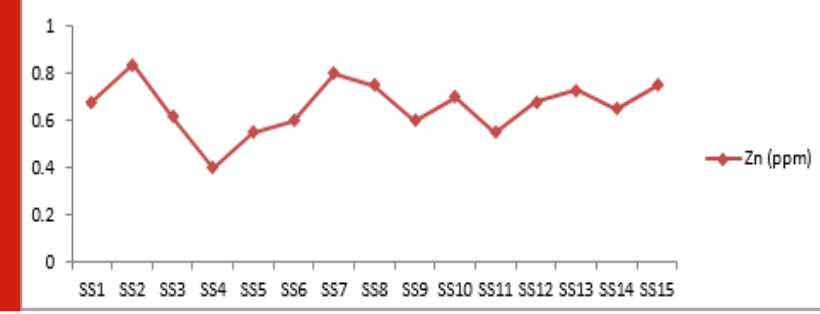

Figure 9: Iron values of all soil samples

\section{$\mathrm{Fe}(\mathrm{ppm})$}

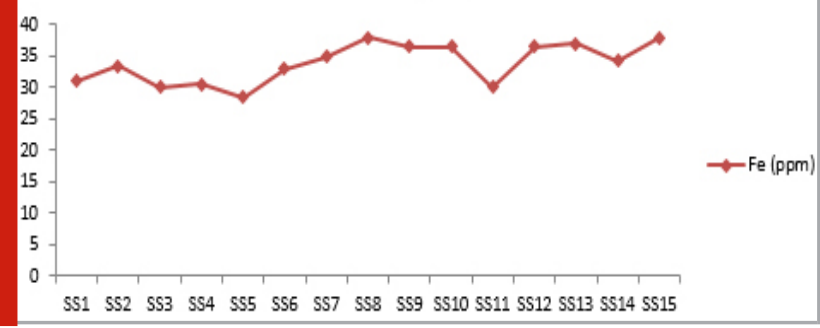

Figure 10: Boron values of all soil samples

B (ppm)

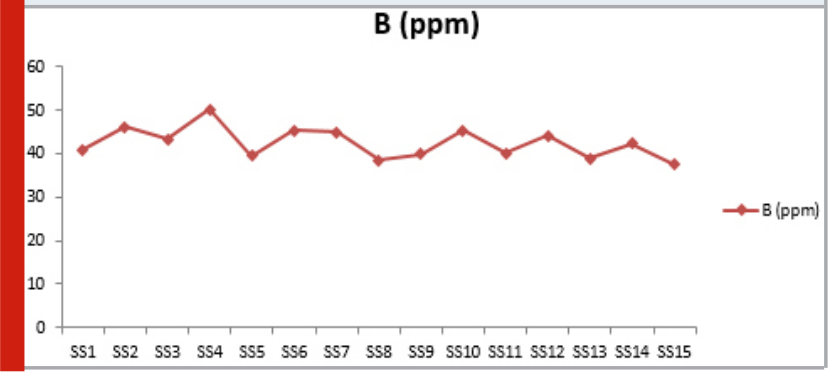


also increased the supply of major and micronutrients. Most farmers are using excessive chemical fertilizers from the results of our study, and the excessive dose of such fertilizers in few soils has yielded high $\mathrm{P}$ and $\mathrm{K}$ values. $\mathrm{K}$ retention may also be due to the clay minerals produced by basalt chemical weathering, which is the parent material for the soil. In most soil samples, the values of $\mathrm{Fe}, \mathrm{Mn}$ and $\mathrm{Zn}$ are greater than the normal range, which may be due to poor drainage conditions in this region, which also makes the soil alkaline. For this cause, the use of acidic fertilizers and organic manure can be a solution that can increase crop yield. Farmers arrange the amount of fertilizers and nutrients needed for soil to increase the percentage yield of crops according to this information.

\section{ACKNOWLED GEMENTS}

I am thankful to research advisor, and research laboratory. Thiru.Vi.Ka. Government. Arts. College. Thiruvarur, for providing necessary facilities.

\section{REFERENCES}

A F Aiyesanmi, AE Okoronkwo,; OM Sunday; Archives of Applied Science Research,, 2012, 4 (1):360-371.

Aiswal P.C., 2011 Soil Plant and Water Analysis.

C C Trasar, MC Leiros, S Seoane, F. Gilsotres, Soil Biol. Biochem., 2008, 1, 301-307.

Ezhilarasi, G.D., Latchoumi, T.P. and Balamurugan, K., 2020. UIP - A Smart Web Application to Manage Network Environments, Advances in Intelligent systems and computing book series.

Gupta A K, MLVarshaney; Practical Manual for Agricultural Chemistry. Kalyani Publisher., 1994.

I.Ifenna; LC.Osuji; Archives of Applied Science Research.,2013, 5 (3):184-192.

K K Borah;, B.Bhuyan; HP Sharma; Archives of Applied Science Research. 2009, 1 (2) 159-164.

K Kanimozhi; A Panneerselvam; Archives of Applied
Science Research., 2011, 3 (2):525 536.

K P Kordlaghari; SN Sisakht; A. Saleh; Annals of Biological Research., 2013, 4 (3):105-108.

K Rajendren, R Veeraputhiran, Agric. Rev., 2001, 22(1), 68-70.

M M Lakdawala; D H Patel; Der Chemica Sinica,, 2013, 4(4):73-77

Methods Manual -Soil Testing in India", Department of Agriculture \& Cooperation Ministry of Agriculture Government of India 2011.

Milka Brdar-Jokanovi. C., Int. J. Mol. Sc. 2020, 21, 1424.

Mishra, P., Jimmy, L., Ogunmola, G.A., Phu, T.V., Jayanthiladevi, A. and Latchoumi, T.P., 2020, December. Hydroponics cultivation using real time iot measurement system. In Journal of Physics: Conference Series (Vol. 1712, No. 1, p. 012040). IOP Publishing.

M C Onojake; LC Osuji; Archives of Applied Science Research. 2012, 4 (1):48-58

N N Garba; A.Isma'lla; UK Asma; ZN Garba; B.I Tijjni,;European Journal of Applied Engineering and Scientific Research., 2013, 2 (2):23-27.

N S Sonawane; CP Sawant;, RV Patil; Archives of Applied Science Research., 2013, 5 (2):294-298.

Prasath, S. (2020). Probabilistic Mceliece Public-Key Cryptography Based Identity Authentication For Secured Communication In Vanet. Solid State Technology, 63(6), 10167-10182.

Prasath, S. Validating Data Integrity in Steganographed Images using Embedded Checksum Technique. International Journal of Computer Applications, 975, 8887.

Venkata Pavan, M., Karnan, B. and Latchoumi, T.P., 2021. PLA-Cu reinforced composite filament: Preparation and flexural property printed at different machining conditions. Advanced Composite Materials, https://doi. org/10.1080/09243046.2021, 1918608. 